\title{
Gene Expression Profiling in Hereditary, BRCA1-linked Breast Cancer: Preliminary Report
}

\author{
Volha Dudaladava 1,2, Michał Jarząb', Ewa Stobiecka ${ }^{3}$ Ewa Chmielik³, Krzysziof Simek , Tomasz Huzarski', Jan Lubiński, \\ Jolanta Pamuła', Wioletta Pękala', Ewa Grzybowska', Katarzyna Lisowska'
}

\begin{abstract}
'Department of Tumor Biology, Maria Skłodowska-Curie Memorial Cancer Center and Institute of Oncology, ${ }^{2}$ permanent address: Institute of Genetics and Cytology, NAS, Minsk, Belarus, ${ }^{3}$ Department of Pathology, Maria Skłodowska-Curie Memorial Cancer Center and Institute of Oncology, ${ }^{4}$ Institute of Automatic Control, Silesian University of Technology, Gliwice, ${ }^{5}$ International Hereditary Cancer Center, Pomeranian Medical University, Szczecin, Poland
\end{abstract}

Key words: hereditary breast cancer, DNA microarrays

Corresponding author: Katarzyna Lisowska, PhD, Department of Tumor Biology, Maria Skłodowska-Curie Memorial Cancer Center and Institute of Oncology, Gliwice Branch, Wybrzeże Armii Krajowej 15, 44-101 Gliwice, Poland, tel. +4832 27898 88, fax +4832 23135 12, e-mail: kasial@io.gliwice.pl

Submitted: 13 January 2006

Accepted: 30 January 2006

Abbreviations: CK5/6, CK14, CK1 7 - cytokeratines 5/6, 14 i 17; FANCA - Fanconi Anemia complementation group A protein; PCA - Principal Component Analysis; SEPHS2 - selenophosphate synthetase 2; TOB 1 - transducer of ERBB2 gene; XRCC5 - X-ray repair complementing defective repair in Chinese hamster cells 5

\begin{abstract}
Global analysis of gene expression by DNA microarrays is nowadays a widely used tool, especially relevant for cancer research. It helps the understanding of complex biology of cancer tissue, allows identification of novel molecular markers, reveals previously unknown molecular subtypes of cancer that differ by clinical features like drug susceptibility or general prognosis. Our aim was to compare gene expression profiles in breast cancer that develop against a background of inherited predisposing mutations versus sporadic breast cancer. In this preliminary study we analysed seven hereditary, BRCAl mutation-linked breast cancer tissues and seven sporadic cases that were carefully matched by histopathology and ER status. Additionally, we analysed 6 samples of normal breast tissue. We found that while the difference in gene expression profiles between tumour tissue and normal breast can be easily recognized by unsupervised algorithms, the difference between those two types of tumours is more discrete. However, by supervised methods of data analysis, we were able to select a set of genes that may differentiate between hereditary and sporadic tumours. The most significant difference concerns genes that code for proteins engaged in regulation of transcription, cellular metabolism, signalling, proliferation and cell death. Microarray results for chosen genes (TOB1, SEPHS2) were validated by real-time RT-PCR.
\end{abstract}

\section{Introduction}

DNA microarrays have been recently widely employed in studies on breast cancer encompassing research on breast cancer cell lines and resected tumo- ur tissues. Two directions of these studies seem to be especially spectacular and promising: the studies of the Norwegian/Stanford group that led to the recognition of several distinct molecular classes of breast cancers $[1,2]$ and the studies of a group at the Nether- 
lands Cancer Institute, which brought identification of a 70-gene prognostic profile for patients with node-negative breast cancer $[3,4]$. The results of those studies indicate that gene expression analysis by DNA microarrays may help the understanding of the molecular background underlying development and progression of breast cancer as well as providing a clinically useful tool for more personalized treatment [reviewed in: 5]. It seems clear that a multi-gene approach will prove more useful and informative than currently used analysis of single markers.

Since the identification of two major predisposing genes, BRCA1 and BRCA2, and broad application of genetic testing, significant numbers of mutation carriers have been identified worldwide among breast cancer patients. This allowed further studies in order to estimate clinical features of those specific breast cancer cases. Some indications are accumulating that mutation-linked breast cancer may be a clinically distinct entity from the majority of malignant breast tumours. Among the characteristics of BRCA1 tumours are: earlier age of manifestation, high tumour grade, low oestrogen receptor content and elevated lymphocyte infiltration. In addition, these cases are often characterized by high proliferative activity, resulting in tumours with pushing margins and high mitotic index [6-12]. The data concerning survival in BRCA 1 mutation carriers are confusing. There are intriguing observations that despite adverse prognostic indications, patients with BRCA1 mutations have survival rates similar to or even better than patients with sporadic breast cancer [13-15, own unpublished data]. The long-term aim of our study is an attempt to elucidate the molecular basis underlying described discrepancies by comparing gene expression profiles of BRCA 1 -associated hereditary breast cancer and sporadic breast cancer cases. The first attempt to compare hereditary versus sporadic breast cancers by DNA microarray analysis was published by Hedenfalk et al., who used cDNA microarrays containing 6512 cDNA clones [16]. In our study we used HG U133 Plus 2.0 Gene Chip (Affymetrix), allowing detection of over 47,000 transcripts. We also attempted to make a more careful selection of tumour specimens, which were chosen exclusively from among ER(-) cases. Our group of tumours was also more uniform according to histopathology; only ductal carcinomas and medullary carcinomas, all grade 3, were analysed.

\section{Materials and methods}

Tissue samples. Frozen surgical specimens of breast cancer and adjacent normal breast tissue were ob- tained from the Pomeranian Medical Academy in Szczecin. Only tissues from patients without preceding chemotherapy were used for microarray experiments. For this initial study we chose seven cancer tissues from women with germline mutation in the BRCAl gene and seven samples of sporadic breast cancer. Three cases had mutation C61G in exon 5, one at 4153 delA in exon 11 , and three harboured the 5382ins $C$ mutation in exon 20. Sporadic cases were obtained from women without a family history of breast/ovarian cancer, in which, additionally, the three most common BRCA1 mutations in Poland were excluded by genetic tests. Eight cases were diagnosed as grade 3 medullary or atypical medullary carcinoma, and 5 cases were grade 3 ductal carcinomas. All tumours were ER negative (immunohistochemistry on paraffin-embedded material). The percentage of cancer cells within tumour specimens was estimated by a pathologist; in the majority of samples it ranged from $70 \%$ to $90 \%$, while in 3 samples it was approx. $50 \%$. In addition, we analysed six samples of unchanged glandular tissue surrounding the tumour and obtained during mastectomy. The lack of tumour samples from BRCA2 mutation carriers in our study reflects the specificity of the mutational spectrum in BRCA genes in Central-Eastern Europe, where BRCA2 mutations are very rare (it was estimated by sequencing that BRCA2 mutations account for only about $5 \%$ of all BRCA1 and BRCA2 mutations found in Polish families with a strong familial history of breast/ovarian cancer [17]). In total we analysed 14 tumour samples and 6 normal breast samples.

RNA isolation. 20-40 mg of frozen tissue was placed in a lysing solution (4M guanidine thiocyanate, 25 $\mathrm{mM}$ sodium citrate, $0.5 \%$ sodium $\mathrm{N}$-laurylsarcosinate, $0.1 \mathrm{M} \beta$-mercaptoethanol) and homogenized with Lysing Matrix D in a FastPrep instrument (QBioGene). Total RNA was extracted from the supernatant according to [18]. RNA cleanup and simultaneous on-column digestion of DNA traces with DNAse I (Qiagen) was done using the RNeasy Mini Kit (Qiagen), according to the manufacturer's instructions. RNA quantity was estimated with the ND-1000 Spectrophotometer (NanoDrop Technologies). RNA quality was controlled by microcapillary electrophoresis measurements in the Agilent 2100 Bioanalyzer using the RNA 6000 Nano LabChip Kit and analysed with RNA Integrity Number software (Agilent).

Oligonucleotide microarrays. We used HG U133 Plus 2.0 Gene Chip oligonucleotide arrays (Affymetrix). The hybridization target was prepared according to recommendations of microarray manufacturer. Briefly: $8 \mu \mathrm{g}$ of 


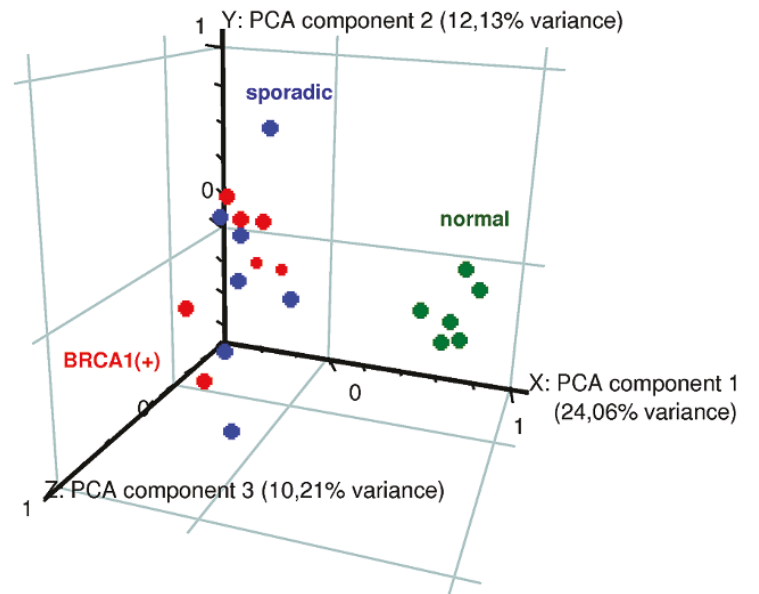

Fig. 1. Principal component analysis (PCA) performed on the whole set of 20 samples. The tumor (red and blue) vs. normal (green) difference is clearly visible within the $1^{\text {st }}$ component, which accounted for $24.06 \%$ of total variance. PCA is unable to reveal a difference between hereditary (red) and sporadic tumors (blue)

total RNA was used for synthesis of double stranded cDNA, half volume of CDNA was used for synthesis of biotynylated cRNA with the BioArray High Yield RNA Transcript Labeling Kit (Enzo Diagnostics). Both cDNA and cRNA were purified with Gene Chip Sample Cleanup Module (Affymetrix). $16 \mathrm{~g}$ of cRNA was fragmented and hybridized to the microarray for $16 \mathrm{~h}$ at $45^{\circ} \mathrm{C}$. After washing and staining microarrays were scanned with $\mathrm{Ge}-$ neChip Scanner 3000 (Affymetrix).

Statistical analysis of microarray data. Data were obtained using GCOS 1.2 software (Affymetrix). The preprocessing was performed by Robust Multi-Array Analysis (RMA). Hierarchical clustering, Principal Component Analysis (PCA) and supervised comparisons were carried out using GeneSpring 7.2 software (Silicon Genetics). For selection of genes differentially expressed between breast cancer and normal breast tissue we used the parametric Welch test. False Discovery Rate was estimated by Benjamini-Hochberg algorithm. For selection of genes differentially expressed between hereditary and sporadic breast cancer we used the Bioconductor limma package, based on linear models with empirical Bayesian approach. This method provides stable results even when the number of analysed arrays is small.

Quantitative RT-PCR. Quantitative RT-PCR analysis was performed using the ABI 7700 Sequence Detection System and dedicated software (Applied Biosystems). The reactions were performed using the MasterAmp Real-Time RT-PCR Kit (Epicentre), according to the manufacturer's recommendations. Primers for the SYBR Green system were designed using Primer3 online software (http://frodo.wi.mit.edu/cgi-bin/primer3/primer3_www.cgi). All results were normalised to the expression of the reference gene, eukaryotic translation initiation factor 4 gamma 2 (EIF4G2), which appeared to be equally transcribed in all tissues analysed by microarrays. Primer specificity was verified by sequencing of selected RT-PCR products for each gene. Sequences of the PCR primer pairs used for each gene are shown in Table 1.

\section{Results}

Unsupervised analysis of obtained data set. We performed Principal Component Analysis (PCA) to determine the major sources of variability in our data (Fig. 1). PCA is an unsupervised algorithm, which, if performed 'on conditions', is able to detect intrinsic similarities and differences in the gene expression profiles of analysed samples. Results may be graphically presented and the distances between the dots visualize the level of similarity/dissimilarity between particular samples. It can be seen that the difference in gene expression profile between breast cancer tissue and normal breast tissue is large and is easily recognized by that unsupervised algorithm (normal-tumour difference was responsible for the sample subdivision by the first component, which accounted for $24.06 \%$ of total variance). Using a supervised method of data analysis we fo-

Table 1. Primers used for quantitative RT-PCR

\begin{tabular}{|c|c|c|c|}
\hline Gene & Oligonucleotide & Sequence & product size \\
\hline SEPHS2 & $\begin{array}{l}\text { forward primer } \\
\text { reverse primer }\end{array}$ & 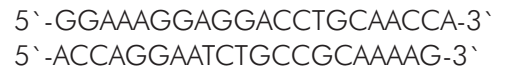 & $154 \mathrm{bp}$ \\
\hline TOB 1 & $\begin{array}{l}\text { forward primer } \\
\text { reverse primer }\end{array}$ & $\begin{array}{l}5^{`} \text { - }-t g \text { tttctacgacatggtattgcattta-3` } \\
5^{`} \text { - caagtattcgtacattttaattccaccact-3 }\end{array}$ & $182 \mathrm{bp}$ \\
\hline EIFG2 & $\begin{array}{l}\text { forward primer } \\
\text { reverse primer }\end{array}$ & $\begin{array}{l}5^{`} \text { '-GCAAGGCTTTGTTCCAGGTGA-3`' } \\
5^{`} \text {-AGGCTTTGGCTGGTTCTTTAGTCA-3` }\end{array}$ & $100 \mathrm{bp}$ \\
\hline
\end{tabular}


und that this precise separation of cancer versus normal tissues in PCA may be ascribed to the differential expression of 8,063 genes (Welch test, Benjamini-Hochberg correction for multiple comparisons, FDR $<0.05$ ). In contrast, the difference between hereditary and sporadic breast cancer samples cannot be recognized by $P C A$, suggesting that the difference in gene expression profile between those two types of breast cancer is not very powerful. Samples obtained from normal glandular breast tissue clustered closely together, while tumours were much more dispersed. By unsupervised analysis we were unable to disclose any differences between hereditary and sporadic tumours; they were not visible also when only cancer samples were subjected to decomposition into principal components (data not shown).

Genes differentiating between hereditary and sporadic breast tumours. As the unsupervised method showed that the distance between hereditary and sporadic tumours is not large and taking into account the limited number of samples in our analysis, we chose a supervised algorithm with a good balance of sensitivity and specificity of analysis. We used the limma package [19], a Bayesian method based on linear modelling with moderated t-statistic.

We selected 100 genes best differentiating between the two analysed groups, ranked according to the statistical power of the expression change (Table 2.). Four times more probe sets were down-regulated in hereditary tumours (78 probesets) in comparison to up-regulated transcripts (22 probe sets). Down-regulated genes showed an average decrease of 1.35 to 5 -fold, up-regulated genes were changed by a factor of 1.2-7.8. Among the first hundred genes selected by limma the most prominent classes consisted of genes connected with regulation of transcription (19 genes), metabolism (12 genes), protein synthesis and degradation (10 genes), cellular signalling (8 genes), cell proliferation and death (6 genes) and DNA and RNA replication and processing (5 genes).

Figure 2 shows that use of a set of 100 genes for hierarchical clustering results in almost perfect classification of hereditary and sporadic tumour samples. Only one sporadic sample falls into the branch of hereditary cases.

Within a set of 100 genes selected in our study, we found genes coding for proteins known to be interacting with the BRCA1 pathway, such as Fanconi Anemia complementation group A gene (FANCA, increased 2-fold) and XRCC5 (50\% decrease), which are both engaged in double-strand break repair. FANCA protein is a component of the multi-subunit FA complex which takes part in sensing and/or regulation of the DNA damage response. The FA complex activates FANCD2 protein which is further targeted to the BRCA1 nuclear loci. Inactivation of the FA/BRCA pathway leads to chromosomal instability, due to impaired DNA repair [20]. DNA repair protein XRCC5 (80 kDa Ku autoantigen) is the DNA-binding component of the DNA-dependent protein kinase, and functions together with the DNA ligase IV-XRCC4 complex in the repair of DNA double-strand break by non-homologous end joining [21].

The TOB 1 gene (transducer of ERBB2 gene, decreased in hereditary tumours) encodes a member of the tob/btg 1 family of anti-proliferative proteins that have the potential to regulate cell growth, and is probably engaged in several human tumours (breast, lung, thyroid) [22-25]. This protein inhibits $T$ cell proliferation and transcription of cytokines and cyclins. This is the only gene from Hedenfalk's list [15] that appears within the first 100 genes selected by limma.

Another interesting gene is selenophosphate synthetase 2 (SEPHS2, decreased in hereditary tumours). This protein encodes an enzyme that synthesizes selenophosphate from selenide and ATP. Selenophosphate is the selenium donor used to synthesize selenocysteine, which is co-translationally incorporated into selenoproteins at in-frame UGA codons. This protein itself contains a selenocysteine residue in its predicted active site. It has been proposed that the effects of selenium in preventing cancer and neurological disorders may be mediated by selenium-binding proteins [26].

The most prominent among genes up-regulated in hereditary carcinomas is a group of immune response genes (5 genes). On the contrary, no immunological genes are found in the list of down-regulated genes. This may reflect a common feature of BRCA 1 -linked breast cancer, i.e. the inflammatory state and lymphocyte infiltrate of a tumour. It is especially striking as all our tumour samples were inspected by a pathologist, and only pieces of tumour mass without a visible inflammatory state were taken for microarray experiments. Thus we conclude that this immunological imprint must be very prominent in BRCA1 $(+)$ breast cancer.

Validation of microarray results by $Q$ RT-PCR. We selected TOB 1 and SEPHS2 genes (see Table 1) for further analysis by quantitative RT-PCR. We examined 
Table 2. Genes differentiating between hereditary, BRCA1-positive breast cancers and sporadic tumours, selected by limma. Genes are ordered according to the fold change value and grouped into functional classes (according to Gene Ontology annotation, http://www.geneontology.org//

\begin{tabular}{|c|c|c|c|c|}
\hline Affy_ID & $\begin{array}{l}\text { Gene } \\
\text { Symbol }\end{array}$ & Gene Title & $\begin{array}{l}\text { Fold change } \\
\text { BRCA } 1(+) \\
\text { vs. sporadic }\end{array}$ & $\begin{array}{l}\text { limma } \\
\text { rank }\end{array}$ \\
\hline
\end{tabular}

\section{Down-regulated in $\operatorname{BRCA1}(+)$}

\begin{tabular}{|c|c|c|c|c|}
\hline \multicolumn{5}{|c|}{ Cell proliferation and death } \\
\hline 202704_at & TOB 1 & transducer of ERBB2, 1 & 0.364 & 75 \\
\hline 243031_at & RTN4 & Reticulon 4 & 0.421 & 71 \\
\hline 1556049_at & RTN4 & reticulon 4 & 0.506 & 46 \\
\hline 215070 x_at & RABGAP1 & RAB GTPase activating protein 1 & 0.731 & 97 \\
\hline \multicolumn{5}{|l|}{ Cell signalling } \\
\hline 1553986_at & RASEF & RAS and EF-hand domain containing & 0.25 & 49 \\
\hline 244181_at & PIK3R 1 & Phosphoinositide-3-kinase, regulatory subunit 1 (p85 alpha) & 0.381 & 80 \\
\hline 238176_at & RAPGEF2 & Rap guanine nucleotide exchange factor (GEF) 2 & 0.461 & 58 \\
\hline 229261_at & SOS1 & Son of sevenless homolog 1 (Drosophila) & 0.565 & 92 \\
\hline 215992_s_at & RAPGEF2 & Rap guanine nucleotide exchange factor (GEF) 2 & 0.583 & 90 \\
\hline 207822_at & FGFR1 & $\begin{array}{l}\text { fibroblast growth factor receptor } 1 \text { (fms-related tyrosine kinase 2, } \\
\text { Pfeiffer syndrome) }\end{array}$ & 0.704 & 82 \\
\hline \multicolumn{5}{|l|}{ DNA and RNA } \\
\hline 233007_at & $\mathrm{XRCC5}$ & $\begin{array}{l}\text { X-ray repair complementing defective repair } \\
\text { in Chinese hamster cells } 5 \text { (double-strand-break rejoining; } \\
\text { Ku autoantigen, } 80 \mathrm{kDa} \text { ) }\end{array}$ & 0.667 & 22 \\
\hline 230651_at & THOC2 & THO complex 2 & 0.414 & 45 \\
\hline 243908_at & ZNF638 & Zinc finger protein 638 & 0.531 & 17 \\
\hline 218356_at & FTSJ2 & FtsJ homolog 2 (E. coli) & 0.699 & 57 \\
\hline \multicolumn{5}{|l|}{ Metabolism } \\
\hline 239545_at & CAS1 & O-acetyltransferase & 0.331 & 26 \\
\hline 238563_at & TPRT & Trans-prenyltransferase & 0.351 & 14 \\
\hline 215316_at & HIBADH & 3-hydroxyisobutyrate dehydrogenase & 0.539 & 30 \\
\hline 200961_at & SEPHS2 & selenophosphate synthetase 2 & 0.576 & 72 \\
\hline 202282_at & $\mathrm{HADH} 2$ & hydroxyacyl-Coenzyme A dehydrogenase, type II & 0.585 & 2 \\
\hline 238813_at & ALAS2 & $\begin{array}{l}\text { Aminolevulinate, delta-, synthase } 2 \\
\text { (sideroblastic/hypochromic anemia) }\end{array}$ & 0.607 & 7 \\
\hline 232127_at & CLCN5 & Chloride channel 5 (nephrolithiasis 2, X-linked, Dent disease) & 0.626 & 33 \\
\hline 218124_at & RetSat & all-trans-13,14-dihydroretinol saturase & 0.63 & 67 \\
\hline \multicolumn{5}{|c|}{ Protein synthesis and degradation } \\
\hline 240146_at & CAPZA2 & Capping protein (actin filament) muscle Z-line, alpha 2 & 0.267 & 28 \\
\hline
\end{tabular}


Table 2. Continuation

\begin{tabular}{|c|c|c|c|c|}
\hline 235138_at & PUM2 & Vacuolar protein sorting 35 (yeast) & 0.287 & 25 \\
\hline 1560926_at & PPP4R2 & Protein phosphatase 4 , regulatory subunit 2 & 0.323 & 88 \\
\hline 1554638_at & ZFYVE16 & zinc finger, FYVE domain containing 16 & 0.43 & 56 \\
\hline 238303_at & SIMP & Source of immunodominant MHC-associated peptides & 0.432 & 35 \\
\hline 232216_at & YME1L1 & YME 1 -like 1 (S. cerevisiae) & 0.443 & 87 \\
\hline 239175_at & AFTIPHILIN & Aftiphilin protein & 0.486 & 4 \\
\hline 222499_at & MRPS 16 & mitochondrial ribosomal protein S16 & 0.537 & 62 \\
\hline 202347_s_at & HIP2 & huntingtin interacting protein 2 & 0.565 & 8 \\
\hline 214843_s_at & USP33 & ubiquitin specific protease 33 & 0.695 & 61 \\
\hline \multicolumn{5}{|c|}{ Regulation of transcription } \\
\hline 1559949_at & TRPS 1 & Trichorhinophalangeal syndrome I & 0.199 & 69 \\
\hline 210282 at & ZNF198 & zinc finger protein 198 & 0.25 & 44 \\
\hline 202600_s_at & NRIP1 & nuclear receptor interacting protein 1 & 0.282 & 70 \\
\hline 243792 x_at & PTPN13 & $\begin{array}{l}\text { Protein tyrosine phosphatase, non-receptor type } 13 \\
\text { (APO-1/CD95 (Fas)-associated phosphatase) }\end{array}$ & 0.36 & 43 \\
\hline 222320_at & HRPT2 & Hyperparathyroidism 2 (with jaw tumor) & 0.403 & 11 \\
\hline 222544_s_at & WHSC1L1 & Wolf-Hirschhorn syndrome candidate 1-like 1 & 0.408 & 18 \\
\hline 222313_at & CNOT2 & CCR4-NOT transcription complex, subunit 2 & 0.412 & 15 \\
\hline 216022_at & WNK1 & WNK lysine deficient protein kinase 1 & 0.414 & 31 \\
\hline 235409_at & MGA & MAX gene associated & 0.443 & 40 \\
\hline 212881_at & PIAS4 & protein inhibitor of activated STAT, 4 & 0.448 & 55 \\
\hline 227798_at & SMAD1 & SMAD, mothers against DPP homolog 1 (Drosophila) & 0.45 & 16 \\
\hline 213766_x_at & GNA1 1 & \multicolumn{2}{|l|}{ guanine nucleotide binding protein ( $G$ protein), alpha 11 (Gq class) 0.487} & 39 \\
\hline 217550_at & ATF6 & Activating transcription factor 6 & 0.518 & 94 \\
\hline 222180_at & YES 1 & V-yes-1 Yamaguchi sarcoma viral oncogene homolog 1 & 0.604 & 98 \\
\hline 218955_at & BRF2 & $\begin{array}{l}\text { BRF2, subunit of RNA polymerase III transcription initiation } \\
\text { factor, BRF1-like }\end{array}$ & 0.635 & 83 \\
\hline 212079_s_at & MLL & $\begin{array}{l}\text { myeloid/lymphoid or mixed-lineage leukemia } \\
\text { (trithorax homolog, Drosophila) }\end{array}$ & 0.666 & 29 \\
\hline 213944 x_at & GNA1 1 & \multicolumn{2}{|l|}{ guanine nucleotide binding protein (G protein), alpha 11 (Gq class) 0.693} & 59 \\
\hline \multicolumn{5}{|l|}{ Other } \\
\hline 1559496_at & --- & $\cdots$ & 0.284 & 5 \\
\hline 234032_at & --- & PRO1550 & 0.289 & 19 \\
\hline 242343_x_at & ZNF518 & Zinc finger protein 518 & 0.309 & 68 \\
\hline 221543_s_at & $\mathrm{SPFH} 2$ & SPFH domain family, member 2 & 0.322 & 6 \\
\hline 204148_s_at & $\begin{array}{l}\text { ZP3 /// } \\
\text { POMZP3 }\end{array}$ & $\begin{array}{l}\text { zona pellucida glycoprotein } 3 \text { (sperm receptor) /// } \\
\text { POM (POM121 homolog, rat) and ZP3 fusion }\end{array}$ & 0.324 & 65 \\
\hline
\end{tabular}


Table 2. Continuation

\begin{tabular}{|c|c|c|c|c|}
\hline 232489_at & FLJ10287 & hypothetical protein FLJ10287 & 0.33 & 1 \\
\hline 236841_at & FLJ25222 & CXYorf1-related protein & 0.334 & 60 \\
\hline 227931_at & --- & MRNA; cDNA DKFZp686D22106 (from clone DKFZp686D22106) & 0.382 & 54 \\
\hline 238706_at & PAPD4 & PAP associated domain containing 4 & 0.386 & 63 \\
\hline 221542_s_at & $\mathrm{SPFH} 2$ & SPFH domain family, member 2 & 0.398 & 24 \\
\hline 231878_at & MVP & Major vault protein & 0.412 & 12 \\
\hline 1564637_a_at & FLJ38426 & hypothetical protein FLJ38426 & 0.47 & 52 \\
\hline 228971_at & --- & -- & 0.476 & 95 \\
\hline 235970_at & MLRI & transcription factor MLR 1 & 0.485 & 73 \\
\hline 230871_at & DHX30 & DEAH (Asp-Glu-Ala-His) box polypeptide 30 & 0.5 & 99 \\
\hline 233228_at & ZNF407 & Zinc finger protein 407 & 0.508 & 48 \\
\hline 237157_at & EVE 1 & $\mathrm{SH} 3$ domain protein $\mathrm{D} 19$ & 0.519 & 9 \\
\hline 215385_at & FTO & Fatso & 0.527 & 41 \\
\hline 222496_s_at & FLJ20273 & RNA-binding protein & 0.528 & 42 \\
\hline 219001_s_at & WDR32 & WD repeat domain 32 & 0.533 & 76 \\
\hline 235927_at & --- & --- & 0.542 & 86 \\
\hline 1569813_at & STRN & striatin, calmodulin binding protein & 0.549 & 66 \\
\hline 240939 x_at & --- & -- & 0.557 & 79 \\
\hline 222642_s_at & TMEM33 & transmembrane protein 33 & 0.558 & 81 \\
\hline 213984_at & SCC-112 & SCC-112 protein & 0.565 & 37 \\
\hline 234488_s_at & $\begin{array}{l}\text { GCL /// } \\
\text { GMCL1L }\end{array}$ & germ cell-less homolog 1 (Drosophila) & 0.619 & 100 \\
\hline 201297_s_at & MOBK1B & MOB1, Mps One Binder kinase activator-like 1B (yeast) & 0.626 & 96 \\
\hline 238660_at & WDFY3 & WD repeat and FYVE domain containing 3 & 0.663 & 13 \\
\hline 212602_at & WDFY3 & WD repeat and FYVE domain containing 3 & 0.708 & 47 \\
\hline 212602_at & WDFY3 & WD repeat and FYVE domain containing 3 & 0.708 & 47 \\
\hline \multicolumn{5}{|c|}{ Up-regulated in $\mathrm{BRCAl}(+)$} \\
\hline \multicolumn{5}{|c|}{ Cell proliferation and death } \\
\hline 203139_at & DAPK 1 & death-associated protein kinase 1 & 1.896 & 74 \\
\hline 209074_s_at & TU3A & TU3A protein & 2.865 & 89 \\
\hline \multicolumn{5}{|l|}{ Cell signalling } \\
\hline 227125_at & IFNAR2 & Interferon (alpha, beta and omega) receptor 2 & 1.791 & 23 \\
\hline 204613_at & PLCG2 & phospholipase C, gamma 2 (phosphatidylinositol-specific) & 2.083 & 20 \\
\hline \multicolumn{5}{|l|}{ DNA and RNA } \\
\hline 203805_s_at & FANCA & $\begin{array}{l}\text { Fanconi anemia, complementation group A /// Fanconi anemia, } \\
\text { complementation group A }\end{array}$ & 2.056 & 93 \\
\hline
\end{tabular}


Table 2. Continuation

\begin{tabular}{|c|c|c|c|c|}
\hline \multicolumn{5}{|l|}{ Immune response } \\
\hline 211530 x_at & HLA-G & HLA-G histocompatibility antigen, class I, G & 1.575 & 38 \\
\hline 205067_at & ILIB & interleukin 1, beta & 1.809 & 78 \\
\hline 205671_s_at & HLA-DOB & major histocompatibility complex, class II, DO beta & 2.37 & 3 \\
\hline 206407_s_at & CCL13 & chemokine (C-C motif) ligand 13 & 2.89 & 10 \\
\hline 234764_x_at & IGLC2 & $\begin{array}{l}\text { Ig lambda chain V-region (VL-AIG) /// } \\
\text { Immunoglobulin lambda variable 3-21 }\end{array}$ & 6.297 & 51 \\
\hline \multicolumn{5}{|l|}{ Metabolism } \\
\hline 222046_at & ARS2 & arsenate resistance protein ARS2 & 1.475 & 77 \\
\hline 204428_s_at & LCAT & lecithin-cholesterol acyltransferase & 1.767 & 27 \\
\hline 208964_s_at & FADS1 & fatty acid desaturase 1 & 1.9 & 64 \\
\hline 1555745_a_at & $L Y Z$ & lysozyme (renal amyloidosis) & 7.787 & 36 \\
\hline \multicolumn{5}{|c|}{ Regulation of transcription } \\
\hline 221010_s_at & SIRT5 & $\begin{array}{l}\text { sirtuin (silent mating type information regulation } 2 \text { homolog) } \\
5 \text { (S. cerevisiae }\end{array}$ & 1.378 & 32 \\
\hline 206090_s_at & DISC 1 & disrupted in schizophrenia 1 & 1.72 & 85 \\
\hline \multicolumn{5}{|l|}{ Other } \\
\hline 237883_at & --- & Transcribed locus & 1.316 & 84 \\
\hline 213938_at & CAST & CAZ-associated structural protein & 1.339 & 53 \\
\hline 1561759_at & --- & Homo sapiens, clone IMAGE:5276804, mRNA & 1.369 & 50 \\
\hline 218600_at & MGC10986 & hypothetical protein MGC10986 & 1.46 & 21 \\
\hline 226410_at & LOC348180 & hypothetical protein LOC348180 & 1.694 & 91 \\
\hline 241383_at & LOC201181 & similar to hypothetical protein A930006D 11 & 2.053 & 34 \\
\hline
\end{tabular}

the expression level of these genes in 12 tumours with mutations in BRCA 1 and 16 tumours without mutation. The results of this analysis were concordant with the microarray results: both genes seem to be down-regulated in BRCA1-linked tumours, when compared to sporadic ones. The difference in expression level of TOB 1 and SEPHS2 genes in BRCA1-linked tumours versus $B R C A 1$ negative tumours was statistically significant ( $p$-value for TOB 1: 0.003, for SEPHS2: 0.005, Kolmogorov-Smirnov test, Fig. 3).

\section{Discussion}

Our preliminary study was done on a relatively small number of cases; however it may be informative, as the samples were chosen carefully. In all previous microarray studies on breast cancer it was observed that the most striking difference in the gene expression profile is connected with oestrogen receptor status. Initially it was stated that ER(+) and ER(-) breast cancers represent distinct categories of breast tumours [27, 28]. More detailed studies performed on a larger set of samples revealed further subtypes, e.g. luminal $A$ and luminal $B$ subtypes among $E R(+)$ tumours and at least two subtypes: ERBB2 + and 'basal' within and ER(-) group [Perou et al., 2000; Sorlie et al., 2001]. Alternatively, another subdivision of ER(-) cases was proposed by Farmer at al., who claim two subgroups: 'basal', characterized by oestrogen and androgen receptors negativity and expression of cytokeratins 5 and 17, and 'molecular apocrine', negative for ER and positive for AR [29]. It was also shown previously that BRCA1 mutation-linked breast cancer tissues cluster within a 'basal' subtype [30]. However, these specific 




Fig. 2. Hierarchical clustering of samples, based on 100 genes differentiating between hereditary and sporadic breast tumors. Colors on the right bar code for: regulation of transcription (orange), cell signalling (blue), cell proliferation and death (black), DNA and RNA replication transcription and processing (red), cellular metabolism (yellow), protein synthesis and degradation (green), immune response (violet) and other (grey). It may be seen, that most prominent cluster of genes upregulated in hereditary tumors consists of genes engaged to immune response, what probably reflects lymphocyte infiltrate of those tumors cases account only for the minority of 'basal' tumours; thus the genes that are differentially expressed between basal and other subgroups do not necessarily reflect a difference in the biology of hereditary (BRCA) -linked) and sporadic carcinomas. Moreover, a set of genes differentiating between breast cancer subtypes in the studies of Perou and Sorlie was selected from genes that are stably expressed in the biopsy specimens, taken from the same tumour before and after chemotherapy. This allowed the construction of so-called 'molecular portraits' of each tumour, but may have eliminated some significant genes that could be suppressed by chemotherapy. In our study we analyse only tumours that have not been subjected to neoadjuvant chemotherapy. To reduce, at least partially, the sources of variability that are not linked to BRCA1 status, we decided to analyse only ER(-) tumour samples.

The aim of our study was to reveal a set of genes differentially expressed between BRCA1 mutation-linked and sporadic breast cancer. Similar study have been performed by Hedenfalk et al., who analysed seven sporadic, seven BRCA1- and eight BRCA2-linked breast cancers and published a set of 51 differentially expressed genes. We tried to retrieve information about expression of those 51 genes from HG U133 Plus 2.0 Gene Chip used in our study. However, due to the incompatibility of both types of DNA microarrays, we were able to find expression data only for 40 genes (represented by 88 probesets). This set of genes was unable to discriminate between sporadic and hereditary cases from our cohort (not shown). This may be caused by shortening of the original list of genes and the fact that the set of 51 genes was selected by comparison of BRCA 1 and BRCA2 tumours with the sporadic ones, all of them of rather mixed histopathology, grade and ER status. Of the genes from Hedenfalk's list only one (TOB1) is represented, at the 62nd position, in our list of 100 genes selected by limma.

It should be mentioned that Jazaeri et al., who analysed a cohort of hereditary and sporadic ovarian cancers, found by the unsupervised method of data analysis that BRCA1 and BRCA2 tumours localize separately from each other, while sporadic cases were placed by the algorithm between these two groups, some of them being closer to BRCA1 tumours, others to BRCA2 tumours [31]. This result confirms all previous observations that $\mathrm{BRCA} 1$ and $\mathrm{BRCA} 2$ mutation-linked carcinomas are different entities, and suggests that at least in some sporadic cases BRCA1 or BRCA2 pathways may be truncated, thus accounting for BRCA1-like and BRCA2-like sporadic tumours. It should be veri- 



Fig. 3. Real-time quantitative PCR validation of microarray results for two selected genes. Box-and-whisker plot represent median and quartile values, with non-outlier range denoted by whiskers and outliers marked by asterisks and circles. Statistical comparison was performed by Kolmogorov-Smirnov test

fied whether this hypothesis applies also to breast cancer. Interestingly, in our group of samples Jazaeri's set of genes performed better than a set published by Hedenfalk [15] (not shown).

Prediction of BRCA status in patients with breast cancer on the basis of clinical and molecular features would be very useful for genetic counselling and for cost-reduction of genetic screening [32, 33]. It was shown recently by Lakhani et al., 2005, that ER status together with immunochemistry for some markers of 'basal' subtype (CK14, CK5/6, CK17 and osteonectin) is better able to predict BRCA1 mutation status in breast cancer patients than previously used criteria [34]. Although it must be experimentally proven, we believe that among 100 genes selected by limma some markers may appear to improve the specificity of prediction of BRCAl status.

\section{Acknowledgments}

This work was supported by grant PBZ-KBN-040/P04/2001, from the State Committee for Scientific Research. Volha Dudaladava is a fellow of a Fellowship Programme totally supported by the National Cancer Institute - Office for International Affairs, NIH, Bethesda, MD, USA

\section{References}

1. Perou $C M$, Sorlie T, Eisen MB, van de Rijn M, Jeffrey SS, Rees $C A$, Pollack JR, Ross DT, Johnsen H, Akslen LA, Fluge $O$, Pergamenschikov A, Williams C, Zhu SX, Lonning PE, Borresen-Dale AL, Brown PO and Botstein D. Molecular portraits of human breast tumours. Nature 2000; 406: 747-752.
2. Sorlie T, Perou CM, Tibshirani R, Aas T, Geisler S, Johnsen H, Hastie T, Eisen MB, van de Riin M, Jeffrey SS, Thorsen T, Quist $\mathrm{H}$, Matese JC, Brown PO, Botstein D, Eystein Lonning P and Borresen-Dale AL. Gene expression patterns of breast carcinomas distinguish tumor subclasses with clinical implications. Proc Natl Acad Sci U S A 2001; 98: 10869-10874.

3. van 't Veer LJ, Dai H, van de Vijver MJ, He YD, Hart AA, Mao M, Peterse HL, van der Kooy K, Marton MJ, Witteveen AT, Schreiber GJ, Kerkhoven RM, Roberts C, Linsley PS, Bernards R and Friend SH. Gene expression profiling predicts clinical outcome of breast cancer. Nature 2002; 415: 530-536.

4. van de Vijver MJ, He YD, van'ł Veer LJ, Dai H, Hart AA, Voskuil DW, Schreiber GJ, Peterse JL, Roberts C, Marton MJ, Parrish M, Atsma D, Witteveen A, Glas A, Delahaye L, van der Velde T, Bartelink H, Rodenhuis S, Rutgers ET, Friend SH and Bernards $R$. A gene-expression signature as a predictor of survival in breast cancer. N Engl J Med 2002; 347: 1999-2009.

5. Jeffrey SS, Lonning PE and Hillner BE. Genomics-based prognosis and therapeutic prediction in breast cancer. J Natl Compr Canc Netw 2005; 3: 291-300.

6. Pathology of familial breast cancer: differences between breast cancers in carriers of BRCA1 or BRCA2 mutations and sporadic cases. Breast Cancer Linkage Consortium. Lancet 1997; 349: 1505-1510.

7. Lakhani SR. The pathology of familial breast cancer: Morphological aspects. Breast Cancer Res 1999; 1: 31-35.

8. Osin PP and Lakhani SR. The pathology of familial breast cancer: Immunohistochemistry and molecular analysis. Breast Cancer Res 1999; 1: 36-40.

9. Van de Vijver MJ. The pathology of familial breast cancer: The pre-BRCA1/BRCA2 era: historical perspectives. Breast Cancer Res 1999; 1: 27-30.

10. Chappuis PO, Nethercot $V$ and Foulkes WD. Clinico-pathological characteristics of BRCA1 - and BRCA2-related breast cancer. Semin Surg Oncol 2000; 18: 287-295.

11. Foulkes WD, Metcalfe K, Sun P, Hanna WM, Lynch HT, Ghadirian P, Tung N, Olopade OI, Weber BL, McLennan J, Olivotto IA, Begin LR and Narod SA. Estrogen receptor status in BRCA1- 
and BRCA2-related breast cancer: the influence of age, grade, and histological type. Clin Cancer Res 2004; 10: 2029-2034.

12. Eerola H, Heikkila P, Tamminen A, Aittomaki K, Blomqvist $C$ and Nevanlinna H. Relationship of patients' age to histopathological features of breast tumours in BRCA1 and BRCA2 and mutation-negative breast cancer families. Breast Cancer Res 2005; 7: R465-469.

13. Marcus JN, Watson P, Page DL, Narod SA, Lenoir GM, Tonin P, Linder-Stephenson L, Salerno G, Conway TA and Lynch HT. Hereditary breast cancer: pathobiology, prognosis, and BRCAl and BRCA2 gene linkage. Cancer 1996; 77: 697-709.

14. Verhoog LC, Brekelmans CT, Seynaeve C, van den Bosch LM, Dahmen G, van Geel AN, Tilanus-Linthorst MM, Bartels CC, Wagner A, van den Ouweland A, Devilee P, Meiiers-Heiiboer EJ and Klijn JG. Survival and tumour characteristics of breast-cancer patients with germline mutations of BRCA1. Lancet 1998; 351: 316-321.

15. Veronesi A, de Giacomi C, Magri MD, Lombardi D, Zanetti M, Scuderi C, Dolcetti R, Viel A, Crivellari D, Bidoli E and Boiocchi $M$. Familial breast cancer: characteristics and outcome of BRCA 1-2 positive and negative cases. BMC Cancer 2005; 5:70-76.

16. Hedenfalk I, Duggan D, Chen Y, Radmacher M, Bittner M, Simon R, Meltzer P, Gusterson B, Esteller M, Kallioniemi OP, Wilfond B, Borg A and Trent J. Gene-expression profiles in hereditary breast cancer. N Engl J Med 2001; 344: 539-548.

17. Górski B, Jakubowska A, Huzarski T, Byrski T, Gronwald J, Grzybowska E, Mackiewicz A, Stawicka M, Bębenek M, Sorokin D, Fiszer-Maliszewska L, Haus $O$, Janiszewska $H$, Niepsuj $S$, GóźdźS, Zaremba L, Posmyk M, Płużańska M, Kilar E, Czudowska D, Waśko B, Miturski R, Kowalczyk JR, Urbański K, Szwiec M, Koc J, Dębniak B, Rozmiarek A, Dębniak T, Cybulski C, Kowalska E, Tołoczko-Grabarek A, Zajączek S, Menkiszak J, Mędrek K, Masojć B, Mierzejewski M, Narod SA, Lubiński J. A high proportion of founder BRCAl mutations in Polish breast cancer families. Int J Cancer 2004; 1 10: 683-686.

18. Chomczynski P and Sacchi N. Single-step method of RNA isolation by acid guanidinium thiocyanate-phenol-chloroform extraction. Anal Biochem 1987; 162: 156-159.

19. Smyth GK. Linear models and empirical Bayes methods for assessing differential expression in microarray experiments. Statistical Applications in Genetics and Molecular Biology 2004; 3 (1): Article 3

20. D'Andrea AD and Grompe M. The Fanconi anaemia/BRCA pathway. Nat Rev Cancer 2003; 3: 23-34.

21. Thacker J and Zdzienicka MZ. The XRCC genes: expanding roles in DNA double-strand break repair. DNA Repair (Amst). 2004; 3: 1081-1090.

22. Yoshida Y, Nakamura T, Komoda M, Satoh H, Suzuki T, Tsuzuku JK, Miyasaka T, Yoshida EH, Umemori H, Kunisaki RK, Tani K, Ishii S, Mori S, Suganuma M, Noda T and Yamamoto T. Mice lacking a transcriptional corepressor Tob are predisposed to cancer. Genes Dev 2003; 17: 1201-1206.

23. Klebig C, Seitz S, Korsching E, Kristiansen G, Gustavus D, Scherneck $S$ and Petersen I. Profile of differentially expressed genes after transfer of chromosome 17 into the breast cancer cell line CAL51. Genes Chromosomes Cancer 2005; 44: 233-246.

24. Iwanaga K, Sueoka N, Sato A, Sakuragi T, Sakao Y, Tominaga

M, Suzuki T, Yoshida Y, K-Tsuzuku J, Yamamoto T, Hayashi S, Nagasawa $\mathrm{K}$ and Sueoka E. Alteration of expression or phosphorylation status of tob, a novel tumor suppressor gene product, is an early event in lung cancer. Cancer Lett 2003; 202: 71 -79.

25. Ito $Y$, Suzuki T, Yoshida H, Tomoda C, Uruno T, Takamura $Y$, Miya A, Kobayashi K, Matsuzuka F, Kuma K, Yamamoto T and Miyauchi A. Phosphorylation and inactivation of Tob contribu- tes to the progression of papillary carcinoma of the thyroid. Cancer Lett 2005; 220: 237-242.

26. Dodig S, Cepelak I. The facts and controversies about selenium. Acta Pharm 2004; 54: 261-276.

27. Gruvberger S, Ringner M, Chen Y, Panavally S, Saal LH, Borg A, Ferno M, Peterson C and Meltzer PS. Estrogen receptor status in breast cancer is associated with remarkably distinct gene expression patterns. Cancer Res 2001; 61: 5979-5984.

28. Pusztai L, Ayers M, Stec J, Clark E, Hess K, Stivers D, Damokosh A, Sneige N, Buchholz TA, Esteva FJ, Arun B, Cristofanilli M, Booser D, Rosales M, Valero V, Adams C, Hortobagyi GN and Symmans WF. Gene expression profiles obtained from fine-needle aspirations of breast cancer reliably identify routine prognostic markers and reveal large-scale molecular differences between estrogen-negative and estrogen-positive tumors. Clin Cancer Res 2003; 9: 2406-2415.

29. Farmer $P$, Bonnefoi $H$, Becette $V$, Tubiana-Hulin M, Fumoleau $P$, Larsimont D, Macgrogan G, Bergh J, Cameron D, Goldstein D, Duss S, Nicoulaz AL, Brisken C, Fiche M, Delorenzi M and Iggo R. Identification of molecular apocrine breast tumours by microarray analysis. Oncogene 2005; 24: 4660-4671.

30. Sorlie T, Tibshirani R, Parker J, Hastie T, Marron JS, Nobel A, Deng S, Johnsen H, Pesich R, Geisler S, Demeter J, Perou CM, Lønning PE, Brown PO, Børresen-Dale AL and Botstein D. Repeated observation of breast tumor subtypes in independent gene expression data sets. Proc Natl Acad Sci U S A 2003; 100 : 8418-8423.

31. Jazaeri AA, Yee CJ, Sotiriou C, Brantley KR, Boyd J and Liu ET. Gene expression profiles of BRCA1-linked, BRCA2-linked, and sporadic ovarian cancers. J Natl Cancer Inst 2002; 94: 990 1000.

32. Vahteristo P, Eerola $H$, Tamminen A, Blomqvist $C$ and Nevanlinna $\mathrm{H}$. A probability model for predicting BRCA1 and BRCA2 mutations in breast and breast-ovarian cancer families. $\mathrm{Br} J \mathrm{Can}$ cer 2001; 84: 704-708.

33. Frank TS, Deffenbaugh AM, Reid JE, Hulick M, Ward BE, Lingenfelter B, Gumpper KL, Scholl T, Tavtigian SV, Pruss DR and Critchfield GC. Clinical characteristics of individuals with germline mutations in BRCA1 and BRCA2: analysis of 10,000 individuals. J Clin Oncol 2002; 20: 1480-1490.

34. Lakhani SR, Reis-Filho JS, Fulford L, Penault-Llorca F, van der Vijver M, Parry S, Bishop T, Benitez J, Rivas C, Bignon YJ, Chang- Claude J, Hamann U, Cornelisse CJ, Devilee P, Beckmann MW, Nestle-Kramling C, Daly PA, Haites N, Varley J, Lalloo F, Evans G, Maugard C, Meijers-Heijboer H, Klijn JG, Olah E, Gusterson BA, Pilotti S, Radice P, Scherneck S, Sobol H, Jacquemier J, Wagner T, Peto J, Stratton MR, McGuffog L, Easton DF and Breast Cancer Linkage Consortium. Prediction of BRCAl status in patients with breast cancer using estrogen receptor and basal phenotype. Clin Cancer Res 2005; 11: 5175-5180. 